\title{
Sexual Harassment and the Role of Human Resource Administration
}

\author{
*Emerson Reid and Prof. Vencie B. Allida, PhD \\ School of Graduate Studies and Leadership, Northern Caribbean University, Jamaica \\ *Corresponding Mail: vencie.allida@ncu.edu.jm
}

\begin{abstract}
Sexual harassment has gained a lot of attention in recent times. Research has indicated that both men and women are victims of sexual harassment and that gender is not a predictor of sexual harassment. One research has suggested that men were harassed twice as much as women, but women were harassed more frequently. The findings in this paper indicate that sexual harassment impact victims in many ways including psychologically and economically. Sexual harassment also impacts productivity and the economy due to low morale, productivity, absenteeism and presenteeism. Since human resource is the most important resource, sexual harassment is a human resource administrator function. Therefore, sexual harassment is gender neutral as both men and women are victims but women are harassed more frequently and pay a higher price physically, mentally and economically. It is therefore recommended that HRA can take steps to create a safe environment for workers where it clearly communicates acceptable behavior and educate the workforce about acceptable behaviors and investigate to eliminate harassment in the workplace.
\end{abstract}

Keywords: Sexual harassment, human resource administration (HRA), productivity, economy

\section{Introduction}

Sexual harassment is widespread and has become a global spotlight in recent times as more women, especially female celebrities, activists and others from the professional status quo began to speak up and speak out more about their experiences (Garrido \& Zaptsi, 2021; Jain-Link, Bourgeois, \& Kennedy, 2019; Center for Talent Innovation, 2018). This fiery issue has had its flames fanned in recent times, driven largely by the \#MeToo social media campaign. Men of power and prestige, fame and wealth, and the upper echelons of society who have enjoyed the global spotlight have had 'bad light' shun on them as they have been accused of sexual harassment.

\section{What is Sexual Harassment?}

The Equal Employment Opportunity Commission (EEOC) provides a comprehensive definition of sexual harassment as the "unwelcome sexual advances, requests for sexual favors and other verbal or physical conduct of a sexual nature constituting sexual harassment when this conduct explicitly or implicitly affects an individual's employment, unreasonably interferes with an individual's work performance or creates an intimidating, hostile or offensive work environment" (Equal Employment Opportunity Commission, 2018).

Merriam-Webster (2018) Dictionary informs that sexual harassment negatively affects the victims' work performance as well as psychological health and well-being. Additionally, it may create an offensive, hostile or intimidating work environment resulting in emotional deterioration and reduction in productivity. Succinctly stated, sexual harassment hurt victims and has a negative spin-off on businesses. Sexual harassment can come in many forms "ranging from offensive materials in the workplace to sexual comments and inappropriate touching" (Gruber, 1990). Sexual harassment "can occur as either a single isolated incident or repeated incidents over time" (MacKinnon, 1979). Sexual harassers can be anybody from customer to client and from subordinate to superior, man or woman of any profession or socioeconomic status (Wikipedia, 2018).

While delivering his throne speech in the Jamaican parliament, the Governor General, Sir Patrick Allen, 
announced that the sexual harassment Bill will be tabled this year and will seek to protect women and men from various sexual harassments that negatively affect their "quality of life by creating an intimidating, hostile or offensive environment." Furthermore, he noted that the "Gender Advisory Council is also to be established....to provide direct oversight for implementation of the National Strategic Action Plan for Gender-based Violence (The Jamaica Gleaner, 2018; Smith, 2018). This council may be akin to the EEOC in the US which provides oversight and enforcement of the Discrimination and Harassment Actt (Equal Employment Opportunity Commission, 2018).

\section{Sexual harassment in the workplace}

Aaron (2018) pointed out that in Jamaica, men have the habit of "forcing their sexual desires on women in society" in very strong and sometimes subtle ways. He cited that "there are numerous cases of sexual harassment of women that exist in our Jamaican society almost daily.... such harassment exists on our streets, in our workplaces and in virtually in every sphere where men and women interact." Khumalo (2021) in her study of female principals in South Africa concluded that sexual harassment is entrenched in schools, given the prevalence and frequency at which female principals are harassed by superiors and subordinates alike.

Komaromy, Bindman, Haber and Sande (1993) in their research on the prevalence of sexual harassment in medical school indicated that "a large percentage of medical students (36 to 52) reported experiencing some form of sexual harassment during medical school" and that "such harassment creates a high level of stress." In addition, the experience of sexual harassment "created a hostile environment or interfered with their performance at work." Rotenstein and Jena (2018) seem to agree with Kamaromy and colleagues, arguing that harassment is quite "common in academic medicine" and begins early in training. They insist that due to sexual harassment and discrimination, female doctors are more likely to leave academic medicine which would have serious "social and economic costs, from compromised patient outcomes and satisfaction to hampered health care availability" on the health care system. Not only is sexual harassment common among medical students, but it is also endemic among health professionals. Campbell (2019) reported that one fifth of doctors surveyed in the UK indicated that doctors have been sexually harassed by both patients and their colleagues alike. This issue weakens doctors mental health, places patents' health at risk and is financially burdensome as funds are budgeted for mental health support (Campbell, 2019).

While research has clearly publicized that the victims of sexual harassment are mostly women (Folkes, 2017), McCabe and Hardman (2005) informs that "women are not the only targets" of sexual malpractice. In fact, sexual harassment is "gender-neutral" (Aaron, 2018, Lazard, 2020) for "in recent times, more men are reporting cases of sexual harassment." Folkes (2017) and Wilson (2013) concur by saying that "sexual harassment continues to be a major issue for members of both sexes who are being harassed by other men or women in the workplace." In one study, it was revealed that " $30.6 \%$ of the male respondents had been harassed compared to $11.1 \%$ females" and that women harassed men twice as much as men did, but women were harassed more frequently.

Another study highlighted that gender was not a "predictor of sexual harassment perpetrators" (Boateng, Bismark, Akaffo, \& Yamoah, 2015). In a 2017 YouGov poll conducted in the US, "15\% of men reported having been sexually harassed at work" while $30 \%$ of "women had been subjected to harassment." The poll results also inform that "one in four US adults (25\%) have witnessed a colleague being sexually harassed in the workplace" (Bame, 2017). Rabinowitz (2018) stated with brevity that, "sexual harassment in the workplace is ubiquitous."

\section{The Double Edge Sword of Sexual Harassment}

$\mathrm{Au}$ (2019) pointed out that "sexual harassment causes tremendous damage to employees who experience it, leading to higher employee turnover, lower employee productivity, increased absenteeism and increased sick leave costs for companies." The World Bank (2020) in its annual publication of its research findings on the impact of gender inequalities and sexual harassment and violence against women and its impact on economies around the world stated, "sexual harassment not only reduces employees' productivity, leading to a higher employee turnover and increased absenteeism, but also is associated with a decrease in companies' returns and profitability" (p. 15). The revelations imply there are two major ways in which sexual harassment is detrimental. It hurts both people and the economy. It affects victims 
Several women who have reported being sexually harassed have experienced "marginalization, retaliation and stigmatization" (Jags, 2018). On the other hand, Lazard (2020) shared that men who have been sexual harassed have been marginalized and suffer psychologically. Researchers have also discovered several other "negative effects" linked to sexual harassment "including emotional problems, anger, stress and anxiety. Women experiencing sexual harassment reported that their job performance suffers. They take sick days and may transfer or quit rather than continue to endure harassing behaviors (Welsh, 1999; MacKinnon, 1979). Folkes (2017) stated that "in many sexual harassment cases, women either have been dismissed or have left their job" out of frustration.

Houle, Staff, Mortimer, Uggen and Blackston (2011) in their study of the association between sexual harassment and signs of depression were able to "confirm that sexual harassment is a stressor that is associated with increased depressive symptoms." Their research also reveals that "women and men who experience more frequent sexual harassment at work have significantly higher levels of depressed mood" when compared to those not harassed. Fitzgerald, Drasgow, Hulin, Gefland and Magley (1997) postulated that as a stressor, sexual harassment can "lead to work withdrawal, career instability, job dissatisfaction and poor mental and physical health." The Feminist Majority Foundation (2018) echoes a similar view, observing that "sexual harassment affects women's mental and physical health as well as their social and economic status."

One meta-analysis of 41 studies involving 70,000 samples reveals that sexual harassment is one of the most damaging and pervasive obstacles to women's careers and job satisfaction. The findings reveal that some of the negative outcomes associated with sexual harassment are "decreased job satisfaction, lower organizational commitment, withdrawing from work", mental and physical illness and some symptoms of post-traumatic stress disorder (Willness, Steel \& Lee, 2007).

As far back as 1979, Mackinnon posited that "sexual harassment at work undercuts woman's potential for social equality in two interpenetrated ways: by using her employment position to coerce her sexually or using her sexual position to coerce her economically." Merchant (2017) contended that sexual harassment impact has manifested itself in the loss of skilled women and economic loss due to the number of professional women quitting their jobs to avoid being harassed or because they were harassed. She suggested that every time a woman has to start over it "diminishes her earning power." Jags (2018) explained that "standing up to harassment is clearly hard" indicating that she "gave up a valuable scholarly opportunity just to avoid" a male colleague who she perceived was making sexual advances towards her but didn't confront him.

\section{It hurts Productivity}

O'Blenes (1999) reasoned that there are several "intangible damages" connected to sexual harassment "such as absenteeism, employee turnover, low morale and low productivity." Anyangwe (2018) agrees with O'Blenes but went further elucidating that sexual harassment not only leads to poor morale, performance, and low productivity but also to a "lack of respect for management and reputational damage." Notwithstanding the considerable sums of monies that some companies have paid out to settle sexual harassment allegations, she pointed out that "the costs to business are far harder to quantify" and that "it is very hard to measure the cost of sexual harassment at work."

One study of top-level US firms listed on the stock market with the worse sexual harassment rate from 2011-2017 found that not only do these companies underperform by an average of 19.9 percent or US\$2.1 billion dollars per firm per year but also result in loss of profitability, lower returns on investment and an average rise of 7 percent in labour cost (Au, 2019; $\mathrm{Au}$, Dong and Tremblay, 2021).

In their study on sexual harassment in Cambodia, Lawreniuk and Parson (2017) examined how Turnover, Absenteeism and Presenteeism affected the cost of productivity for the factory and the workers due to sexual harassment. They reported that "both men and women indicated that their productivity was reduced by sexual harassment." While factory turnover cost was low (the costs to hire and train new workers), they estimated that the factory lost over US\$630,000.00 monthly while the costs to "workers who reported productivity losses" amounted to more than US\$7,342,000.00 per month due to presenteeism, which is "working while not in a fully functioning state" of mind leading to the generation of high cost. Their findings revealed that "in total, the costs of absenteeism, presenteeism and turnover amount to US\$88,742,695 per annum." 
In 2005, it was estimated that companies in the United States paid out at least one billion dollars yearly in lawsuit relating to sexual harassment (Boland, 2005) while it is "estimated that workplace sexual harassment will cost Fortune 500 companies in the U.S. approximately $\$ 6.7$ million per year in absenteeism, low productivity and employee turnover (Sbraga \& O'donohue, 2000). Boateng and his colleagues (2015) indicated that turnover cost has been the "largest single component of the overall cost of sexual harassment in the U.S." (p. 141). While the negative impact of sexual harassment has been quite impactful on certain companies around the world, the harsh reality is that we still do not know the real financial cost due to the loss of productivity on local and global economies.

\section{The Need for Sexual Harassment Legislation}

In 2018, the World Bank studied 189 countries with specific legislation that protects against sexual harassment in employment and education and whether there are civil remedies and criminal penalties attached to those legislations. The findings reveal that nearly 60 countries had no law that protects against sexual harassment. It reported that 70 economies in Middle East and North Africa have zero legislation, that one-third of countries in Latin America and the Caribbean did not, while one fourth of economies in Europe and Asia lacked workplace protection against sexual harassment. Furthermore, the reports point out that "without such protections in place, sexual harassment at work can undermine careers, the ability to work and the employment climate" (The World Bank, 2018, p. 20). While most countries have some legislation against workplace sexual harassment, more work and effort needs to be done to change the tide.

Member Governments of the International Labor Organization (ILO) on June 21, 2019 adopted a global treaty aim to improve workplace protection against violence and harassment. It sets out a framework for governments to "take measures to prevent and protect people from violence and harassment and to establish monitoring and enforcement systems, provide for complaints mechanisms and ensure that victims have access to support, services and remedies for victims, including compensation. These policies should include "adopting legal prohibitions of violence and harassment at work and ensuring effective inspections, investigations and protection from retaliation" as well as training and risk assessment measures (Human Rights Watch, 2019, 2020).

\section{Four Ways HRA Can Deal with Sexual Harassment}

The role and function of human resource administration is aptly stated in the following words:
Human resources development is the design, implementation and maintenance of strategies to manage people toward enhancing business performance. This includes developing supporting policies and processes. Human resource constitutes the key factors in the success of any organization. The core aspects the firm must plan for include, getting and keeping good people; training and developing, motivating, and maintaining them (Boateng, et al, 2015).

Dealing with sexual harassment clearly is a human resource function (Kadaba, 2018; Lopez (2017); Koch, 1998). Furthermore, developing strategies to prevent and support victims of sexual harassment is a function of HRA that cannot be overstated or overlooked. Four ways to deal with Sexual harassment are to create, educate, communicate and investigate to eliminate as follows (Fitzwater, 1998):

1. To Create: Organizations must establish polices and guidelines that are comprehensive, clearly defining and explaining sexual harassment and propose steps they will take to deal with harassment in case of breach. A well-crafted policy can serve as an employee relations tool, a means to educate and to help prevent litigation (Wagner, 1992).

2. To Communicate: Organizations should communicate the policy through written sources such as workers handbook or employee manuals (Fitzwater, 1998) and have it distributed to employees, posting it on internet, intranet and other public places in the company. A part of communication is reporting. Proper reporting procedure must also be established to document complaints (Lopez, 2017). Organizations should also establish different methods and channels of reporting such as direct reporting to $H R$, special hotline or HR unit set up for that purpose (Koch, 1998).

3. To Educate: Organizations should conduct regular training programs and seminars annually for supervisors, managers and 
other senior staff members in addition to regular employees - including new recruits - on expected behavior in the workplace, informing steps to take if harassed or accused of harassment.

4. To Investigate and Take Action to Eliminate: Investigation of harassment must be dealt with promptly and disciplinary action where necessary should be executed swiftly (Workforce, 2013; Koch, 1998). Where organizations fail to act, it might prove quite costly.

In addition to these steps, Howard and Lakes (2007) advice that remedies to sexual harassment must be two-fold: restoring victims and preventing reoccurrence. He also suggests a progression of steps in dealing with harassment ranging from warning, suspension and termination based on the severity. Moreover, counselling or harassment seminars (Orlov \& Roumell, 1999) can also be used as corrective methods to handle sexual misconduct. Orlov and Roumell (1999) propose that victims of sexual harassment should be "offered counselling or some other reasonable assistance from employer to deal with the effects of the sexual harassment" which may include transfer, change of schedule or even promotion (Webb \& Norton, 2009).

\section{Conclusions and Recommendations}

This section presents the conclusions of the paper and then gives the recommendations thereof.

\section{Conclusions}

Sexual harassment is real and is everywhere. Both men and women are affected by and are guilty of sexual harassment offences. This malpractice has several negative consequences including physical and mental illnesses in the form of stress, anxiety or depression as well as financial and economic losses to victims, companies and countries due to low morale, performance and productivity. One thing is clear: sexual harassment diminishes the human resources capital in various ways. Sexual harassment is a human resource issue and human resource administrators should take preventative steps to deal with sexual harassment in the workplace. Eradicating sexual harassment can help to boost productivity, the economy and can help to improve lives.

\section{Recommendations}

While there are many ways to deal with sexual harassment in the workspace/workplace, the following are recommended:

1. That more Governments adopt the ILO global treaty on sexual harassment for legislation.

2. Every place of employment, academic institutions and place of training and development needs to develop clear and comprehensive strategic policies for handling sexual harassment prevention, complaints and breach.

3. Organizational leaders should provide appropriate communication and education and training about sexual harassment in its policies, including establishing systems for reporting, investigating and documenting complaints of sexual harassment.

4. Both public and private organizations should appropriately publish their policies on sexual harassment in keeping with national policies.

5. Organizations, where possible, should provide appropriate mental health support and counselling therapy for victims and perpetrators of sexual harassment as a means of providing healing and elimination of the problem. Compensation to victims should also be considered.

6. As much as possible, victims should be allowed paid time off for grief and recovery; transferring to other departments or lines of work within the organization maybe contemplated to avoid stigma and even retaliation.

\section{References}

Aaron, D. (2018, July 6). Do not turn a blind eye to sexual harassment. Jamaica Gleaner. Retrieved July 26, 2018, from http://w ww.jam aicaobserver.com/your-healthyour-wealth/do-not-turn-a-blind-eye-to-sex u al-harassment_121594?profile=1373

Anyangwe, E. (2018, March 14). Sexual harassment: the hidden costs for employers from low productivity to reputational damage, the far-reaching consequences of ineffective policies. The Financial Times. Retrieved July 31, 2018, from https://www.ft.com /conte nt/af64eea0-207f-11e8-8d6c-a1920d9e 946 f. 
$\mathrm{Au}, \mathrm{S}$. (2019). The real cost of workplace sexual harassment to businesses. Retrieved from HYPER LINK"https://theconversat ion.com/t he -real-cost-of-workplace-sexual-harassm ent-to-businesses-\%0912 2107" https:// theconv ersation.com/the-real-cost-ofworkplace-sexual-harassment-to-busin esse s-122107

Au, S., Dong, M. \& Tremblay, A. (2021). Employee Sexual Harassment Reviews and Firm Value. Retrieved from HYPERLINK "http s://paper s.ssrn.com/sol3/papers.cfm?abst ract_id=3437444" https://papers.ssrn .com / so 13/ paper s.cfm?abstract_id $=3437444$

Bame, Y. (2017, April 25). Nearly a third of women have been sexually harassed at work. YOUGOV. Retrieved from https://today. yougov.c om/topics/lifestyle/articlesreport s/2017/04/25/nearly-third-women-have-be e $n$-sexually-harassed-wor

Boateng, P. A., Bismark, E., Akaffo, A. V., \& Yamoah, P. (2015, November). Sexual Harassment and Human Resource Development. European Journal of Business and Management, 7(33), 2222-2839. Retrieved July 25,2018 , from https://www.researchga te.net/publication/298793401

Boland, M. (2005). Sexual Harassment in the Workplace. Cited in Boateng, P.A., et al (2005). Sexual Harassment and Human Resource Development. European Journal of Business and Management, 7(33), 22222839. Retrieved July 25, 2018, from https://www.research, 2222-2839.

Campbell, D. (2019). One in five UK doctors 'suffers or witnesses' sexual harassment. Retrieved from HYPERLINK "https://www.thegu ardian.com/world/2019/oct/01/one-in-fiveuk-doctors-suffers-or-" https://www.the guardian .com/wo rld/2019/oct/01/one-infive-uk-doctors-suffers-or- witnessessexual-harassment.

Center for Talent Innovation (2018).The Pervasiveness of Sexual Harassment in Today's White- Collar Workplace: New Study Reveals the Hard Numbers by Industry, Race, and Gender. Retrieved from HYPERLINK "https://www.prnewswire.co $\mathrm{m} / \mathrm{h}$ ew s-releases/the-pervasiveness-ofsexual-" https://www.prnewswire.com/ne ws-releases/the-pervasiveness-of-sexu alharassment-in-todays-white-collar-wor $\mathrm{kp}$ la ce-300679484.htm

Equal Employment Opportunity Commission (2018). Title VII of the Civil Rights Act of 1964. Retrieved from https://www.eeoc.gov/eeoc /publ cations/fs-sex.cfm

The Feminist Majority Foundation. (2018). Retrieved August 9, 2018, from http://www.femini st.org/911/harasswhatdo.html.

Fitzwater, T. (1998). Series: Managers Pocket Guide Series. Amherst, Mass: HRD Press.

Folkes, F. (2017, October 2). Stories of sexual harassment at the workplace. Jamaica Observer. Retrieved July 26, 2018, from http://www.jamaicaobserver.com/all-woma n/stories-of_112061?profile=1332\&t emp lat $\mathrm{e}=$ MobileArticle

Garrido, R. \& Zaptsi, A. (2021). Archetypes, Me Too, Time's Up and the representation of diverse women on TV. Media Education Research Journal, 68(29, 21-32.

Gruber, J. E. (1990). Methodological Problems and Policy Implications in Sexual Harassment Research. Population Research and Policy Review(9), 235-254.

Houle, J. N., Staff, J., Mortimer, J. T., Uggen, C., \& Blackston, A. (2011). The Impact of Sexual Harassment On Depressive Symptoms During The Early Occupational Career. Society of Mental Health, 1(2), 89-105. doi:doi:10.1177/2156869311416827.

Howard, L. G., \& Lakes, F. (2007). The SexualHarassment Handbook: Protect Yourself and Coworkers From the Realities of Sexual Harassment, Take Action, Investigate, and Remedy Accusations of Harassment, Create Corporate Policies That Educate and Empower Employees. Franklin Lakes, NJ: Career Press.

Human Rights Watch (2019). ILO: New Treaty to Protect Workers from Violence, Harassment: Governments Should Ratify to Ensure Safer World of Work. Retrieved from HYPERLINK "https://www.hrw.org/ news/ 2019/06/21/ilo-new-treaty-protect-worke rs-violence-" https://www.hrw.org /new s/2 
019 /06/21/ilo-new-treaty-protect-workersviolence- harassment

Human Rights Watch (2020). Safety and Dignity at Work: A Guide to the 2019 ILO Violence and Harassment Convention. Retrieved from HYPERLINK "https://www.hrw.org/si tes/d efa ult/files/media_2020/06/ILO_advoc acy_brochure_0620.pd" https://w ww.hr w $.0 \mathrm{rg} / \mathrm{sites} /$ default/files/media_2020/06/IL O_advocacy_brochure_0620.pd

$\mathrm{f}$

Jags, R. (2018, January 18). Sexual Harassment in Medicine - \#MeToo. New England Journal of Medicine. Retrieved July 26, 2018, from https://www.nejm.org/doi/full/10.1056/NEJ Mp1715962378:209-211.

Jain-Link, P., Bourgeois, T. \& Kennedy, J. T. (2019). Ending Harassment at Work Requires an Intersectional Approach. Retrieved from HYPERLINK "https://hbr.org/2019/ 04/end ing-harassment-at-" https://hbr.org/2019/0 4/en ding-h arassment-at- work-requiresan-intersectional-approach.

Jamaica Gleaner. (2018, Janaury 29). Retrieved from http://jamaica-gleaner.com/article/news /20180129/sexual-harassment-bill-modifi ed-reflect-current-realities.

Kadaba, L. S. (2018, March 15). Sexual harassment in the \#MeToo era: What's HR's role? The Inquirer. Retrieved from http://www.philly.c om/philly/business/workplaces/sexual-hara ssment-me-too-human-resources-workplac e-2 0180315.html.

Khumalo, S. S. (2021). Analyzing the experiences of women principals in primary schools in Limpopo province, South Africa through social justice theory. Problems of Education in the 21st Century, 79(1), 47-59.

Koch, J. (1998). Steps to Protect Your Company Against Sexual Harassment. Workforce. Retrieved August 9, 2018, from http://www.workforce.com/1998/10/01/ste ps-to-protect-your-company-against-sexualharassment/

Komaromy, M., Bindman, A. B., Haber, R. J., \& Sande, M. A. (1993). Sexual Harassment in Medical Training. New England Journal of Medicine.doi:doi/full/10.1056/NEJM199302 043280507.
Lawreniuk, S., \& Parson, L. (2017). "I know I cannot quit". The Prevalence and Productivity Cost of Sexual Harassment to the Cambodian Garment Industry. Retrieved from https://insights.careinternational.org.uk/pu blications/i-know-i-cannot-quit-the-prevale nce-and-productivity-cost-of-sexual-hara ssment-to-the-cambodian-garment-indusry.

Lazard, L. (2020). The Sexual Harassment of Hollywood Men, In Lazard, L (Editor) Sexual Harassment, Psychology and Feminism: \#MeToo, Victim Politics and Predators in Neoliberal Times, p. 77-104. Cham, Switzerland: Springer.

Lopez, R. (2017, November 21). HR's Role in Handling Sexual Harassment in the Workplace. RMI. Retrieved from http://rmisolutions.com/blog/measuring-managingemployee-performance-drives-businessgrowth/.

MacKinnon, C. A. (1979). The Sexual Harassment of Working Women. New Haven: Yale University Press.

McCabe, M. P., \& Hardman, L. (2005). Attitudes and Perceptions of Workers to Sexual Harassment. Cited in Boateng, P.A., et al (2005). Sexual Harassment and Human Resource Development. Europen Journal of Business Management, 7(33), 2222-2839. Retrieved July 25, 2018, from https://www.researchgate.net/publication/ 298793401.

Merchant, N. (2017, November 29). The Insidious Economic Impact of Sexual Harassment. Havard Business Review. Retrieved July 31, 2018, from https://hbr.org/2017/11/theinsidious-economic-impact-of-sexual-haras sment.

Merriam-Webster (2018). Retrieved August 9, 2018, from https://www.merriam-webster. com/ legal/hostile\%20environment\%20sexual\%20 harassment.

O'Blenes, C. (1999). Harassment Grows More Complex. Management Review, 88(6), 4951.

Orlov, D., \& Roumell, M. T. (1999). What Every Manager Needs to Know About Sexual Harassment. New York: AMACOM. 
Rabinowitz, L. G. (2018, June 14). Recognizing Blind Spots - A Remedy for Gender Bias in Medicine? New England Journal of Medicine(378), 2253-2255. Retrieved July 26, 2018, from https://www.ne jm.org/ doi/full/10.1056/NEJMp1802228 378:22532255 DOI: 10.1056/NEJMp1802228.

Rotenstein, L. S., \& Jena, A. B. (2018, June 14). Lost Taussigs - The Consequences of Gender Discrimination in Medicine. New England Journal of Medecine, 378, 2255-2257. Retrieved July 26, 2018, from https://ww w.ne jm.org/doi/full/10.1056/NEJMp 1801164 378:2255-2257.

Sbraga, T. P., \& O'donohue, W. (2000). Sexual Harassment. Annual Review of Sex Research, 11(1), 258-285.

Smith, A. (2018, February 16). Sexual Harassment Bill to Be Tabled this Year. JIS. Retrieved from https://jis.gov.jm/sexual-harassmentbill-tabled-year/

The World Bank (2018). Women, Business and Law 2018. Retrieved from HYPERLINK "https: //docu ments1.worldbank.org/curate d/en/926401524803880673/pdf/125804PUB-" https://documents1.worldbank.org/ curated/en/926401524803880673/pdf/125 804-PUBREPLACEMENT-PUBLIC.pdf.
The World Bank (2020). Women, Business and Law 2020. Retrieved from https://ope nkno wle dge.worldbank.org/bitstream/handle/10986 /32639/9781464815324.pdf

Wagner, E. J. (1992). Sexual Harassment in the Workplace: How to Prevent, Investigate, and Resolve Problems in Your Organization. New York: AMACOM.

Webb, D. L., \& Norton, M. S. (2009). Human Resources Administration: Personnel Issues and Needs in Education (5th ed.). Upper Saddle River, New Jersey: Merrill (Pearson).

Welsh, S. (1999). Gender and sexual harassment. Annual Review of Sociology, 25, 169-190.

Wikipedia. (2018). Sexual Harassment. Retrieved from https://en.wikipedia.org/wiki/ Sex ual_h arassment

Wilson, N. (2013, August 25). Men, women facing sexual harassment at the workplace. Jamaica Observer. Retrieved July 26, 2018, from http://www.jamaicaobser ver.com/ mag azines/allwoman/Men--women-facingsexual-harassment-at-the-workpla ce_1 488 4886.

Workforce. (2013). Retrieved August 9, 2018, from http://www.workforce.com/2013/03/21/ho w-not-to-respond-to-a-harassment-compl aint/ 